\title{
Oxidant Stress in Hemodialysis
}

\author{
Francesco Galli ${ }^{a}$ Claudio Ronco ${ }^{b}$ \\ ${ }^{a}$ 'G. Fornaini' Institute of Biological Chemistry, University of Urbino and bDepartment of Nephrology, \\ St. Bortolo Hospital, Vicenza, Italy
}

In the last two decades, a growing body of evidence has accumulated suggesting that oxidative stress may be one of the important complications occurring in hemodialysis (HD). This problem may not have immediate clinical effects, but it may represent a long-term complication derived from the repetitive effects of blood-membrane interaction [1-3].

Advanced experimental and clinical investigation regarding the mechanisms of oxidative stress during HD have elucidated the role of blood cell activation, and particularly polymorphonuclear (PMN) leukocytes. However, the multifactorial nature of this process [4] might include other factors peculiar to chronic HD, such as the absence of a complete correction of the uremic toxicity, malnutrition and the progressive worsening of the clinical condition due to aging and comorbidity. Altogether these factors trigger oxidative stress by establishing a steadily abnormal production of prooxidant stimuli coupled with a defective or insufficient antioxidant protection [1-3].

Phagocyte activation can generate reactive oxygen species (ROS) during the so-called respiratory burst [4]. These molecules exert a physiological role participating in

Prof. Claudio Ronco is Visiting Professor of Medicine at Albert Einstein College of Medicine and Director of the Renal Research Laboratory, Division of Nephrology and Hypertension at Beth Israel Medical Center and Renal Research Institute, New York.

\begin{tabular}{ll}
\hline KARGER & ( ) 2000 S. Karger AG, Basel \\
$0028-2766 / 00 / 0841-0001 \$ 17.50 / 0$ \\
Fax +4161306 12 34 & \\
$\begin{array}{l}\text { E-Mail karger@karger.ch } \\
\text { www.karger.com }\end{array}$ & $\begin{array}{l}\text { Accessible online at: } \\
\text { www.karger.com/journals/nef }\end{array}$
\end{tabular}

the killing of bacterial and tumor cells [5] and in cell signaling [6]. From another perspective however, if chemical reactivity of these molecules is not properly controlled and limited, they may become extremely dangerous leading to the oxidative modification of biologically relevant molecules such as lipids, proteins and nucleic acids [2, 4]. Ultimately, a series of acute and chronic responses (damage, repair and adaptation) may arise in tissues and organs, the physiopathological relevance of which has been extensively documented [4, 7]. Oxidative stress has been proposed to play a role in many states often associated with end-stage renal disease, including cardiovascular and infectious diseases, cancer, diabetes, disorders of peripheral and central nervous system, anemia and accelerated aging [1-4]. Even if a direct cause-effect relationship between HD and oxidative stress-related disease states has not been definitively demonstrated, the repeated activation of the immune cells during the extracorporeal treatment may be a key aspect implying the onset of long-term side effects and an increased morbidity and mortality in hemodialysis patients.

Exploring in detail the possible consequences of an increased oxidative stress in HD patients, we may come up with a list of disorders that include:

(1) Lipoprotein modification: this is one of the major events associated with oxidative stress and, together with the ROS damage to endothelial cells, it is considered one of the earliest key events in the formation of atheromatose plaque [8].

Prof. Claudio Ronco, MD

Renal Research Institute

207 East 94 Street, Suite 303

New York, NY 10128 (USA)

Tel. +1 212360 4900, Fax +1 212360 7233, E-Mail cronco@rriny.com 
(2) The recurrent leukocyte stimulation with complement activation and cytokine secretion may lead to a condition of chronic inflammation in which the priming of immune cells can ultimately result in a defective immune response upon specific stimuli [9]. To this immune cell dysfunction may also directly contribute the noxious effects of ROS and the abnormal production of proinflammatory/prooxidant cytokines, particularly TNF- $\alpha$, one of the most powerful cell death triggers [7].

(3) The chronic activation by HD membranes of PMN leukocytes may lead to LDL modification and up-regulation of surface molecules and chemotactic factors which mediate the adhesion to endothelium, and the migration through the endothelial wall of activated phagocytes, thus translating oxidative stress into tissues [10-12].

(4) Other events of possible clinical relevance in the proinflammatory effect of HD are the secretion of acutephase molecules including complement components, Creactive protein and serum amyloid $\mathrm{A}[13,14]$.

(5) The attack of ROS on red blood cell membrane lipids can influence their lifespan and increase their susceptibility to intravascular hemolysis, an important event which perpetuates and further promotes oxidative stress $[3,15]$.

(6) Finally, an important oxidant-related injurious process, occuring particularly in HD patients, is related to an increased formation of reactive carbonyl species derived in large part from the accumulation of protein glycation products and lipid oxidation [16]. As regards the (per)oxidation of cell membrane and plasma lipids, this process induces the formation of bioactive lipids such as prostaglandin-like molecules (i.e. the $\mathrm{F}_{2}$-isoprostanes) with effects on the vascular relaxation and cell function/proliferation [17], and several classes of by-products including reactive carbonyls such as the malondialdehyde (MDA) able to interact with the lysine residues of target proteins with consequent molecular damage [16].

All these damages may occur in conjunction with an imblance between oxidant stress and antioxidant conditions. Some defects in cell defenses and a possible defective antioxidant status in plasma of HD patients have been proposed even though contradictory information appeared in the literature $[1,2]$. A loss through the dialysis membrane of hydrosoluble antioxidants such as ascorbic acid, together with their possible increased consumption by oxidation, may contribute to a decreased antioxidant power of plasma. These factors can be observed in HD together with an increased demand of the liposoluble antioxidant vitamin $\mathrm{E}$, which constitute one of the main defenses against lipid peroxidation in humans [18, 19].
Also protein and free thiols, particularly cysteine residues contained in the albumin and glutathione, can be important targets of the prooxidant effect of the HD and of the uremic condition.

Several efforts have been undertaken by the scientific community and industry to study and develop new technological and clinical solutions to improve dialysis biocompatibility and possibly to eliminate some clinically relevant consequences of the blood-membrane interaction including oxidative stress. Based on the assumption that chronic HD patients may require an increased antioxidant protection, several approaches oriented to providing a supplementation with nonenzymatic antioxidants have been carried out $[2,3]$. Vitamin E, one of the most important naturally occurring antioxidants [19], has been widely used in HD $[2,18]$. Its utilization in supplementation trials has provided the most interesting results as regards the correction of the lipid peroxidation in blood cells and plasma. Although in some studies the serum levels of vitamin $E$ in HD patients have been observed to be in the normal range, interesting results have been provided by supplementation trials $[18,20]$. The protective effects of vitamin $\mathrm{E}$ have been proposed to be mainly directed towards the lipoprotein and erythrocyte membrane lipids [1, 2, 18, 21]. Thus, vitamin E supplementation could be important to lower the atherogenic risk in HD patients $[22,23]$ and in correcting uremic anemia [18, $21,24]$.

In recent years, new approaches to the antioxidant therapy in HD have been introduced [2, 3], namely hemolipodialysis, infusion of antioxidants by dialysate, and vitamin E-bonded membranes.

Even if introduced only in the last years [25], the possibility to bind vitamin $\mathrm{E}$ to membranes is now a clinical reality being used since the early 1990s. The main goals of this technological strategy are the reduction of oxidative stress and the improvement of membrane biocompatibility.

From its introduction in the dialysis practice, this type of membrane has stimulated a particular interest in the international scientific community working in the field of chronic renal replacement therapy, giving origin to a series of investigations [see Contributions to Nephrology vol. 127, 1999]. This recent literature, other than to offer an extensive overview of oxidative stress [2] and vitamin $\mathrm{E}[18]$ in uremia and dialysis, presents several experimental and clinical observations that can be of relevance in understanding the meaning and the potential of this new biomembrane. Meanwhile, the most recent papers in the field could represent a tool for learning and following the 
development of an innovative concept of biocompatibility in which a bioreactive natural molecule can be successfully employed.

The newest scientific production in this field includes technical papers offering an in-depth characterization of development strategy and manufacturing [25], a morphological analysis by infrared imaging [26] and electron microscopy [27] of the multilayer structure/composition of the vitamin E-bonded membrane. Further information is given on the hydraulic and flow dynamic properties [28] and of the low-molecular-weight solute dialysance [29].

Accordingly with early studies $[20,30]$, vitamin E bound to the dialysis membrane surface has been observed to be active in redox cycling accessory antioxidants such as ascorbic acid [31, 32]. This basic finding, together with a possible even if minimal release of vitamin E during HD, might justify the observation of a supplementation effect $[20,21]$ probably mainly due to a sparing effect on the constitutive pool of blood vitamin E. These standing points in understanding the bioreactive properties of the vitamin E-bonded membranes go together with other papers showing how these membranes can improve some antioxidant parameters [32], lower lipid peroxidation both in vitro and in vivo [31,33-36] and slow down advanced glycation end-products (AGEs) accumulation [34]. These observations may support the preliminary evidence of an acute in vitro protection against LDL oxidation [23], partially confirmed by other recent in vivo studies [22].

The use of vitamin E-bonded membranes has also been proposed to lower plasma levels of $\beta_{2}$-microglobulin, possibly by changing its isoelectric point which might influence positively the elimination by dialysis [37].

Two different studies show how the vitamin E-bonded membrane may have a positive effect on uremic anemia increasing the antioxidant protection and lowering membrane peroxidation in red blood cells $[21,24]$. In particular, the use of these modified dialysis membranes combined with the supplementation of reduced glutathione may decrease significantly the requirement for EPO [24]. At the same time, a lower number of dysmorphic erythrocytes is found after dialysis with modified membranes compared with conventional cuprammonium rayon (CR) membranes [38].

Some preliminary lines of evidence have been provided on an improved endothelial function in patients treated for 4 months with vitamin E-bonded membrane as indicated by better ischemia-induced dilatation of forearm arteries [35].
As regards the effect on mononuclear leukocytes, several parameters suggest that their intradialytic activation can be better controlled by vitamin E-modified membrane than CR-based membranes. These include the in vitro responsiveness to stimuli capable of initiating an immunoinflammatory reaction [39], leukopenia [40], cell proliferation/viability [31, 39, 41], the in vivo complement-dependent activation and cytokine release [40-43]. Moreover, PMN leukocytes exposed in vitro to vitamin E-bonded filters generate a smaller amount of ROS when compared to CR [31] or other membranes [33], which may imply a protective effect against oxidative stress. PMN phagocytes obtained form patients treated with these membranes seem to be better preserved in their metabolic integrity and respiratory burst efficacy when compared to other membranes $[31,35,36,43]$.

Altogether the above-mentioned literature offers an extensive view of one of the most recent intriguing subjects in dialysis, namely oxidative stress. Recent papers in this field also offer a tool to both basic researchers and clinicians investigating possible new strategies to improve dialysis biocompatibility. Vitamin E-bonded membranes in fact suggest a new approach in which, for the first time, the concept of bioreactivity has been introduced. It is hoped that thanks to this pioneering work, further scientific efforts may be stimulated in order to obtain a deeper understanding of the properties and possible evolution of newer dialysis membranes acting not only as a semipermeable barrier for solutes and water, but also as biological surfaces interacting with chemical and biological properties of the blood flowing in contact with them.

\section{Acknowledgements}

We thank Dr. Mario Zelioli and Dr. Alessandro Simionato for the information and discussion provided. We are also grateful to Miss Simona Rovidati for her assistance in preparing the manuscript. 


\section{References}

1 Hasselwander O, Young IS: Oxidative stress in chronic renal failure. Free Radic Res 1998;29: $1-11$.

2 Galli F, Canestrari F, Bellomo G: Physiopathology of the oxidative stress and its implication in uremia and dialysis; in Ronco $\mathrm{C}, \mathrm{La}$ Greca G (eds): Vitamin E-Bonded Membrane. A Further Step in Dialysis Optimization. Contrib Nephrol. Basle, Karger, 1999, vol 127, pp $1-31$.

3 Tetta C, Biasioli S, Schiavon R, Inguaggiato P, David S, Panichi V, Wratten ML: An overview of hemodialysis and oxidative stress. Blood Purif 1999;17:118-126.

4 Halliwell B, Gutteridge JMC: Free Radicals in Biology and Medicine, ed 3. Oxford, Oxford University Press, 1999.

5 Rothe G, Valet G: Flow cytometry assay of oxidative burst activity in phagocytes. Methods Enzymol 1994;233:539-548.

6 Suzuki YJ, Forman HJ, Sevanian A: Oxidants a stimulator of signal transduction. Free Radic Biol Med 1997;22:269-285.

7 Galli F, Canestrari F, Buoncristiani U: Biological effects of oxidative stress in hemodialysis. Blood Purif 1999;17:79-94.

8 Ziouzencova O, Sevanian A, Abuja PM, Ramos P, Esterbauer H: Copper can promote oxidation of LDL by markedly different mechanisms. Free Radiol Biol Med 1998;24:607623.

9 Gesualdo L, Pertosa G, Grandaliano G, Schena FP: Cytokine and biocompatibility. Nephrol Dial Transplant 1998;13:1622-1626.

10 Saccini C, Jialal I: LDL modification by activated polymorphonuclear leukocytes: A cellular model of mild oxidative stress. Free Radiol Biol Med 1994;16:49-55.

11 Berliner JA, Territo MC, Sevanian A, Ramin S, Kim JA, Bamshad B, Esterson M, Fogelman AM: Minimally modified low-density lipoprotein stimulates monocyte endothelial interactions. J Clin Invest 1990;85:1260-1266.

12 Klouche M, Gottschling S, Gerl V, Hell W, Husmann M, Dorweiler B, Messner M, Bhakdi $\mathrm{S}$ : Atherogenic properties of enzymatically degraded LDL: Selective induction of MCP-1 and cytotoxic effects on human macrophages. Atheroscler Thromb Vasc Biol 1998;18:13761385.

13 Trznadel K, Luciak M, Paradowski M, Kubasiewicz-Ujma B: Hemodialysis and the acutephase response in chronic uremic patients. Int $\mathrm{J}$ Artif Organs 1989;12:762-765.

14 Owen WF, Lowrie EG: C-reactive protein as an outcome predictor for maintenance hemodialysis patients. Kidney Int 1998;54:627-636.

15 Canestrari F, Galli F, Giorgini A, Galiotta P, Pascucci M, Bossù M: Erythrocyte redox state in uremic anemia: Effects of hemodialysis and relevance of glutathione metabolism. Acta Haematol 1994;91:187-193.

16 Miyata T, van Ypersele de Strihou C, Kurokawa K, Baynes JW: Alterations in nonenzymatic biochemistry in uremia: Origin and significance of 'carbonyl stress' in long-term uremic complications. Kidney Int 1999;55:389-399.
17 Moore KP, Holt SG, Patel RP, Svistunenko DA, Zackert W, Goodier D, Redder BJ, Clozel M, Anand R, Cooper CE, Morrow JD, Wilson MT, Darley-Usmar V, Roberts LJ II: A causative role for redox cycling of myoglobin and its inhibition by alkalinization in the pathogenesis and treatment of rhabdomyolysis-induced renal failure. J Biol Chem 1998;273:3173131737.

18 Taccone-Gallucci M, Lubrano R, Meloni C: Vitamin $\mathrm{E}$ as antioxidant agent; in Ronco C, La Greca G (eds): Vitamin E-Bonded Membrane. A Further Step in Dialysis Optimization. Contrib Nephrol. Basel, Karger, 1999, vol 127, pp 32-43.

19 Diplock AT, Chaleux JL, Crozier-Willi G, Kok FS, Rice-Evans C, Roberfroid M, Stahl W, Wiña-Ribes $\mathrm{J}$ : Functional food sciences and defenses against reactive oxygen species. Br J Nutr 1998;80:S77-S1 12.

20 Galli F, Rovidati S, Chiarantini L, Kulurianu $\mathrm{H}$, Canestrari F, Buoncristiani U: Bioreactivity and biocompatiblity of a vitamin E-modified multi-layer hemodialysis filter. Kidney Int 1998;54:580-589.

21 Taccone-Gallucci M, Meloni C, Lubrano R Morosetti M, Palombo G, Cianciulli P, Scoppi $\mathrm{P}$, Castello MA, Casciani CU: Chronic haemodialysis and erythrocytes survival in haemodialysis patients treated with vitamin E-modified dialysis filter; in Ronco C, La Greca G (eds): Vitamin E-Bonded Membrane. A Further Step in Dialysis Optimization. Contrib Nephrol. Basel, Karger, 1999, vol 127, pp 44-48.

22 Mune M, Yukawa S, Kishino M, Otani H, Kimura K, Nishikawa O, Takahashi T, Kodama N, Saika Y, Yamada Y: Effect of vitamin E on lipid metabolism and atherosclerosis in ESRD patients. Kidney Int 1999;56:S126S129.

23 Morena M, Cristol JP, Descomp B, Canaud B Does vitamin $\mathrm{E}$ bound on dialysis membrane improve the LDL susceptibility to oxidation? Lessons from an in vitro model; in Ronco C, La Greca G (eds): Vitamin E-Bonded Membrane. A Further Step in Dialysis Optimization. Contrib Neprhol. Basel, Karger, 1999, vol 127, pp 128-138.

24 Usberti M, Bufano G, Lima G, Gazzotti RM, Tira P, Gerardi G, Di Lorenzo D: Increased red blood cell survival reduces the need of erythropoietin in hemodialyzed patients treated with exogenous glutathione and vitamin $\mathrm{E}$ modified membrane, in Ronco C, La Greca G (eds): Vitamin E-Bonded Membrane. A Further Step in Dialysis Optimization. Contrib Nephrol. Basel, Karger, 1999, vol 127, pp 208215.

25 Sasaki M, Hosoya N, Saruhashi M: Development of vitamin E-modified membrane; in Ronco C, La Greca G (eds): Vitamin E-Bonded Membrane. A Further Step in Dialysis Optimization. Contrib Nephrol. Basel, Karger, 1999. vol 127, pp 32-43.

26 Stefoni S, Masotti L, Feliciangeli G, Calonghi N, Atti E, De Pascalis A, Donati G, La Manna G, Scolari MP, Bonomini V: Evalua- tion of dialysis membranes through infrared imaging; in Ronco C, La Greca G (eds): Vitamin E-Bonded Membrane. A Further Step in Dialysis Optimization. Contrib Nephrol. Basel, Karger, 1999, vol 127, pp 71-78.

27 Ballestri M, Tonelli M, Inguaggiato P, Albertazzi A: Hollow-fiber dialyzer employing vitamin E-bonded membrane: A morphological analysis; in Ronco C, La Greca G (eds): Vitamin E-Bonded Membrane. A Further Step in Dialysis Optimization. Contrib Nephrol. Basel, Karger, 1999, vol 127, pp 113-127.

28 Brendolan A, Ronco C, Ghezzi MP, La Greca G: Hydraulic characterization of Excebrane ${ }^{\circledR}$ dialyzers; in Ronco C, La Greca G (eds): Vitamin E-Bonded Membrane. A Further Step in Dialysis Optimization. Contrib Nephrol. Basel, Karger, 1999, vol 127, pp 79-88.

29 Locatelli F, Di Filippo S, Manzoni C: Urea clearance and ionic dialysance of Excebrane ${ }^{\circledR}$ hemodialyzers; in Ronco C, La Greca G (eds): Vitamin E-Bonded Membrane. A Further Step in Dialysis Optimization. Contrib Nephrol. Basel, Karger, 1999, vol 127, pp 89-95.

30 Buoncristiani U, Galli F, Rovidati S, Albertini MC, Covarelli C, Canestrari F: Oxidative damage during hemodialysis using a vitamin Emodified dialysis membrane: A preliminary characterization. Nephron 1997;77:57-61.

31 Galli F, Rovidati S, Benedetti S, Canestrari F, Ferraro B, Floridi A, Buoncristiani U: Lipid peroxidation, leukocyte function and apoptosis in hemodialysis patients treated with vitamin E-modified filters; in Ronco C, La Greca G (eds): Vitamin E-Bonded Membrane. A Further Step in Dialysis Optimization. Contrib Nephrol. Basel, Karger, 1999, vol 127, pp 156171.

32 Biasioli S, Schiavon R, Petrosino L, Cavallini L, Cavalcanti G, De Fanti E, Zambello A, Donata B: Effect of several cellulosic dialytic membranes on hyperhomocysteinemia and on the oxidative stress in dialysis patients. Any role for Curay + vit. E?; in Ronco C, La Greca G (eds): Vitamin E-Bonded Membrane. A Further Step in Dialysis Optimization. Contrib Nephrol. Basel, Karger, 1999, vol 127, pp 96112.

33 Gaggi R, Santoro A, Melotti C, Di Stasio D, Parente R, Zucchelli P: A chemiluminescence assay for the detection of reactive oxygen species produced by human neutrophils: In vitro comparison of vitamin E-modified multilayer hemodialysis filter with a polysulphone dialyzer; in Ronco C, La Greca G (eds): Vitamin EBonded Membrane. A Further Step in Dialysis Optimization. Contrib Nephrol. Basel, Karger, 1999, vol 127 pp 216-226.

34 Odetti P, Robaudo C, Valentini S, Gurreri G, Garibaldi S, Angeletti S, Deferrari G: Effect of a new vitamin E-coated membrane on glycoxidation during hemodialysis; in Ronco $\mathrm{C}, \mathrm{La}$ Greca G (eds): Vitamin E-Bonded Membrane. A Further Step in Dialysis Optimization. Contrib Nephrol. Basel, Karger, 1999, vol 127, pp 192-199. 
35 Schiecke G, Gwinner W, Radermaker J, Bahlmann J, Lonnemann G: Long-term effects of vitamin E-bonded dialysis membrane on mononuclear cell activation, malondialdehyde generation and endothelial function in ESRD patients; in Ronco C, La Greca G (eds): Vitamin E-Bonded Membrane. A Further Step in Dialysis Optimization. Contrib Nephrol. Basel, Karger, 1999, vol 127, pp 244-251.

36 Shimazu T, Kondo S, Toyama K, Komurai M, Yasuda T, Sato T, Maeba T, Maruyama H, Owada S, Ishida M: The effect of vitamin Emodified regenerative cellulose membrane on neutrophil superoxide anion radical production and lipid peroxidation; in Ronco C, La Greca G (eds): Vitamin E-Bonded Membrane. A Further Step in Dialysis Optimization. Contrib Nephrol. Basel, Karger, 1999, vol 127, pp 252-261.

37 Brancaccio D, Bellotti V, Losi B, Padovese P, Cozzolino M, Carpani P, Mangione P, Giorgetti S, Galleni M: Effects of vitamin E-modified dialyzer (Excebrane ${ }^{\circledR}$ ) on $\beta_{2}$-microglobulin structure and removal; in Ronco C, La Greca G (eds): Vitamin E-Bonded Membrane. A Further Step in Dialysis Optimization. Contrib Nephrol. Basel, Karger, 1999, vol 127, pp 147155.
38 Calzavara P, De Angeli S, Gatto C, Dugo M, Puggia R, Calconi G: Morphological evaluation of red blood cells using vitamin E-modified dialysis filters; in Ronco C, La Greca G (eds): Vitamin E-Bonded Membrane. A Further Step in Dialysis Optimization. Contrib Nephrol. Basel, Karger, 1999, vol 127, pp 172176.

39 Amato M, Aterini S, Pacini S, Ruggiero M Effect of vitamin E conjugated to dialysis membranes on immunohematopoietic cell growth and signalling; in Ronco C, La Greca G (eds): Vitamin E-Bonded Membrane. A Further Step in Dialysis Optimization. Contrib Nephrol. Basel, Karger, 1999, vol 127, pp 139-146.

40 Ghezzi PM, Ronco C: Excebrane ${ }^{\circledR}$ : Hemocompatibility studied by the intradialytic monitoring of oxygen saturation; in Ronco C, La Greca G (eds): Vitamin E-Bonded Membrane. A Further Step in Dialysis Optimization. Contrib Nephrol. Basel, Karger, 1999, vol 127, pp 177191.
41 Girndt M, Kaul H, Lengler S, Sester U, Sester M, Kolher H: Immunological biocompatibility characterization of vitamin E-bonded membrane; in Ronco C, La Greca G (eds): Vitamin E-Bonded Membrane. A Further Step in Dialysis Optimization. Contrib Nephrol. Basel, Karger, 1999, vol 127, pp 227-243.

42 Petrosa G, Grandaliano G, Valente M, Montinaro V, Soccio M, Gesualdo L, Schena FP: In vivo evaluation of biocompatibility of a new dialyzer employing the vitamin E-mdofied cellulose membrane 'Excebrane E': Study of mechanism involved in mononuclear cell activation; in Ronco C, La Greca G (eds): Vitamin E-Bonded Membrane. A Further Step in Dialysis Optimization. Contrib Nephrol. Basel, Karger, 1999, vol 127, pp 200-207.

43 Sanaka T, Omata M, Niwayama J, Shinobe M, Higuchi C: Suppressive effects of vitamin Ecoated dialysis-membrane on hemodialysis-induced neutrophil activation; in Ronco $\mathrm{C}$, $\mathrm{La}$ Greca G (eds): Vitamin E-Bonded Membrane. A Further Step in Dialysis Optimization. Contrib Nephrol. Basel, Karger, 1999, vol 127, pp 262-269. 